\title{
A Wet Period in the Desert Station in HEIFE
}

\author{
By Ken Sahashi \\ School of Education, Okayama University, Okayama, Japan \\ (Manuscript received 27 April 1995, in revised form 19 September 1995)
}

\begin{abstract}
In the HEIFE area at the northern foot of the Tibetan Plateau, a marked wet period which seems to be accompanied by a monsoon from the Indian Ocean was found in summer. The wet period was often accompanied by precipitation. An noticeable phenomenon is that the precipitation area moves in association with an anticyclone.
\end{abstract}

\section{Introduction}

A Sino-Japanese joint investigation of the atmosphere-land surface interactions experiment at Heihe river basin (HEIFE), in north-west China was carried out from 1988 until 1993.

According to our general understanding, a typical climatic feature in a desert is dryness. Through the observation of HEIFE, however, a rather wet period has been observed in the summer season. In this paper, the fact of that and some considerations of the phenomenon will be described. Most of the precipitation in the HEIFE area arises in the summer season. We will analyze the data obtained in $\mathrm{Au}-$ gust, 1991.

\section{Site and observation}

The HEIFE area is located near the north edge of the Tibetan Plateau and the ground level ranges from $1400 \mathrm{~m}$ to $2000 \mathrm{~m}$ above the sea level.The size of the area is about $70 \mathrm{~km} \times 140 \mathrm{~km}$. A map of the area is shown in Fig. 1a.

In the HEIFE area, we had five basic flux stations with $20 \mathrm{~m}$ or $40 \mathrm{~m}$ high towers, and five automatic weather stations. Among them, data from the following three stations which were run by Japanese were mainly employed in this study: Desert Basic Station (DBS), Zhangye Basic Station (ZBS) and Gobi South Automatic Weather Station (GAS). The location of these observation points is shown in Fig. $1 \mathrm{~b}$.

At DBS and ZBS, we have $20 \mathrm{~m}$-high observation towers. The measurement systems at the sites were supplied by Vaisala and were solar-panel driven and recorded on MILOS-200, EPROMs. We employed the data at the $20 \mathrm{~m}$-level of the tower in the fol-

(C)1995, Meteorological Society of Japan lowing analysis. At GAS, temperature and humidity sensors supplied by Vaisala were installed at the $5 \mathrm{~m}$-level and a wind sensor was installed $7 \mathrm{~m}$ above the ground. Humidity was measured as relative humidity. Atmospheric pressure was also measured at each site. At DBS and ZBS, were rain gauges also supplied by Vaisala. Each signal from the sensor was recorded every $30 \mathrm{~min}$ at DBS and ZBS, and every $10 \mathrm{~min}$ at GAS. In the following analysis, $30 \mathrm{~min}$ data from those three sites were employed to make an inter-comparison.

For a more detailed description of the measuring system and instruments refer to Wang et al. (1993).

\section{Temporal changes of mixing ratio and other related factors}

Figure 2 shows the variations of half-hourly mixing ratio values at DBS. As seen in the figure, the maximum value of mixing ratio in this month is about three times larger than the minimum value. This indicates that there are rather large variations of the moisture content in the desert in summer.

To eliminate the short-term variation, and to make a comparison with the other observation stations easier, daily mean values of mixing ratio were calculated for DBS, ZBS and GAS, temporal changes of which are shown in Fig. 3. There are several wet periods when the mixing ratio is relatively high, that is, 4 th, 7 th to 8 th, 11 th to 13 th and 24 th to 25th of August.

As confirmed in Fig. 3, the patterns of day-to-day variations of the mixing ratio at the three sites are similar to each other. It means that the scale of the phenomenon is at least as large as the size of the HEIFE area $\left(c a .10^{4} \mathrm{~km}^{2}\right)$. Figure 4 shows the variations of the diurnal mean air temperature at the same sites as in Fig. 3. Figure 5 shows the variation 
(a)

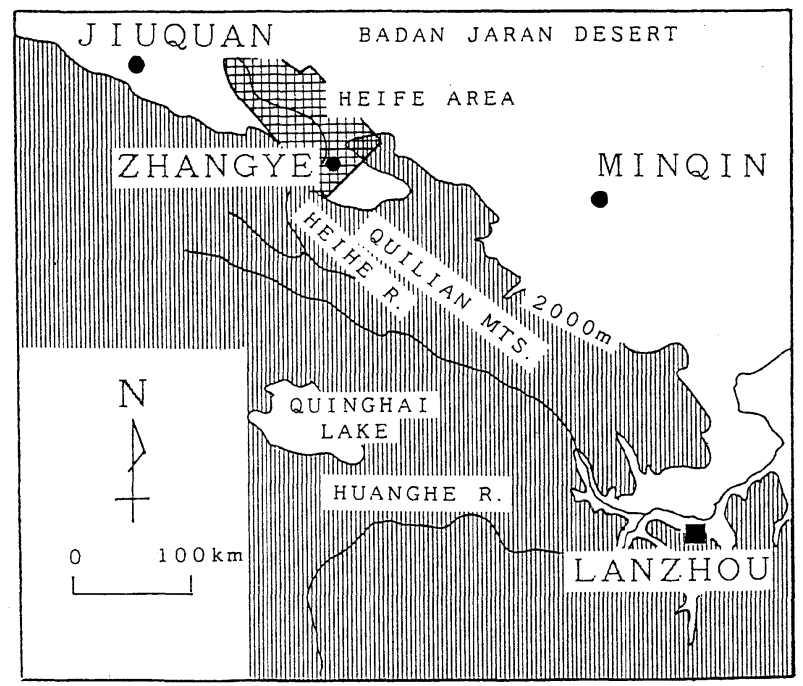

(b)

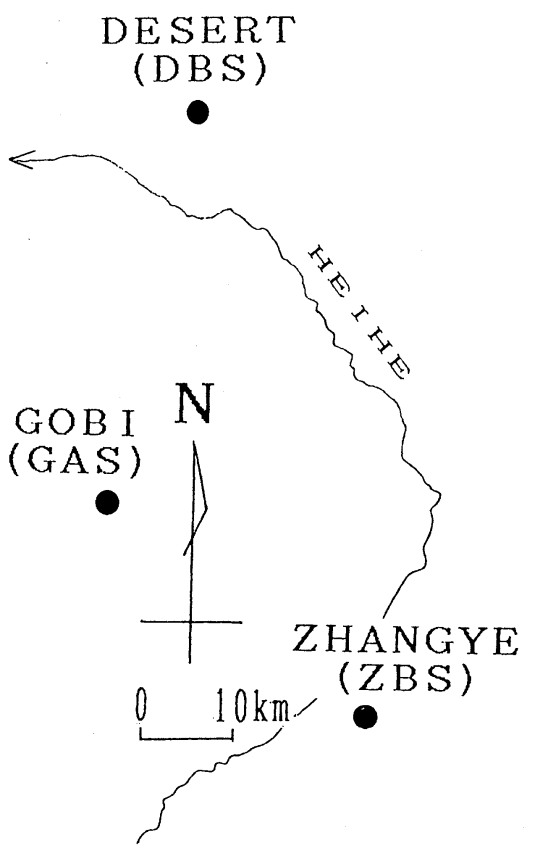

Fig. 1. (a) Map around the HEIFE area. The shaded area shows higher than $2000 \mathrm{~m}$ above the sea-level. The latticed area shows the HEIHE area. (b) Location of the observation site.

$\mathrm{g} / \mathrm{kg}$

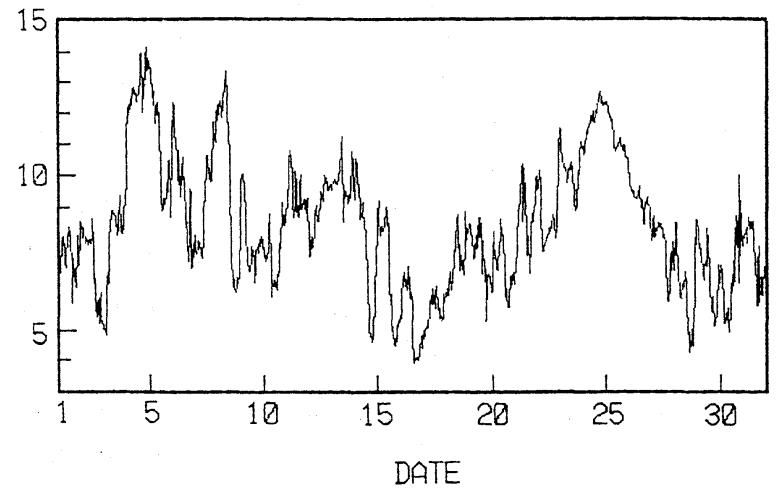

Fig. 2. Variation of mixing ratio in August, 1991 at the Desert Basic Station plotted every $30 \mathrm{~min}$.

of the daily total of solar radiation, and Fig. 6 shows the daily precipitation. These figures also support the estimation of the scale of the phenomenon described above. The change of meteorological factors happens simultaneously at those three sites.

It is shown from Fig. 3 through Fig. 6 that the period of high mixing ratio usually occurs concurrently with a period of lower air temperature, lower solar radiation and with precipitation. The only exception is the second wet period, that is, 7th to 8th. In that period, the mixing ratio is higher but there is no precipitation.

In Fig. 7, the variation of the atmospheric pres-

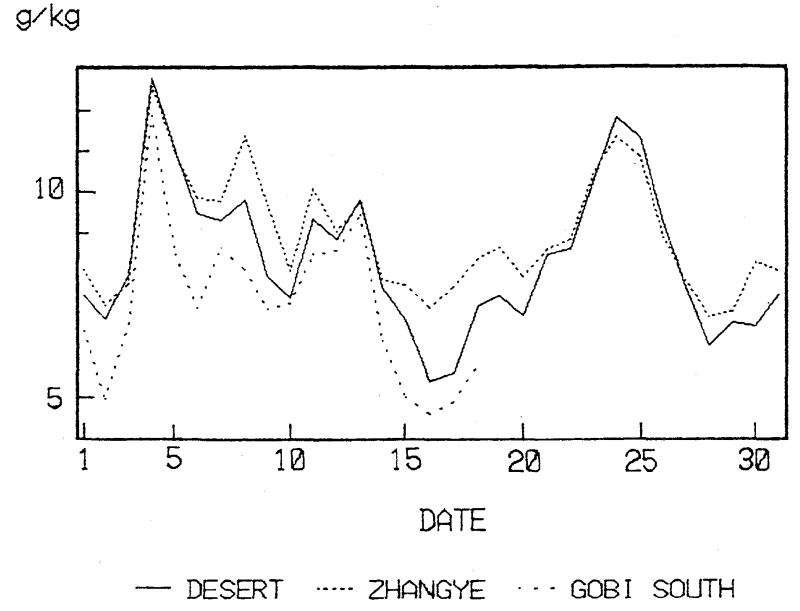

Fig. 3. Variation of mixing ratio at DBS, ZBS and GAS in August, 1991 plotted as a diurnal average.

sure at the three sites in August is shown. Comparing with Figs. 6 and 7, we see that the precipitation is usually associated with a peak of the atmospheric pressure.

\section{Discussions}

Yatagai and Yasunari (1993) pointed out that there is some relation between precipitation in the HEIFE area and the monsoon from India. According to their analysis, a branch of the monsoon, from India to the north-east China, turns round the Ti- 


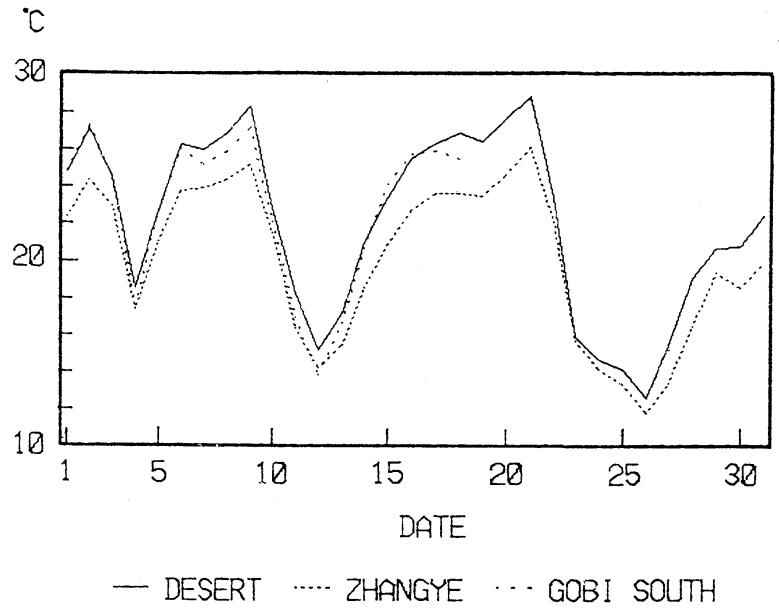

Fig. 4. Same as Fig. 3, but for air temperature.

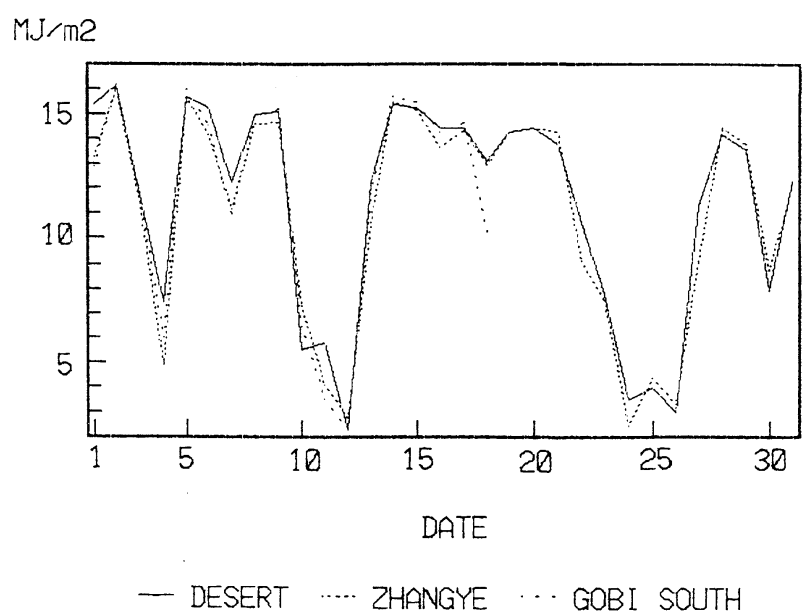

Fig. 5. Same as Fig. 3, but for solar radiation plotted as the diurnal total amount.

betan Plateau and advances to the HEIFE area in summer. In this case, the direction of the branch might be north-easterly to south-easterly.

Yoshino (1993) also noted through statistical analysis the existence of east-north-easterly wind in the northern part of Hexi Corridor in the summer season.

To find the wind direction at the three observation sites during wet period, time changes of the wind direction at the three sites (shown by curves) and precipitation (shown by vertical columns) at DBS are shown in Fig. 8. In this figure, data are plotted every $30 \mathrm{~min}$. This example is the third wet period. We can see that until $20 \mathrm{~h}$ on $12 \mathrm{th}$, the wind directions at the sites were westerly to northerly, after that they changed to easterly to east-south-easterly. Rain started from $18 \mathrm{~h}$ on 12 th and ended at $6 \mathrm{~h}$ on 13th. It means that change in the wind direction was accompanied by the occurrence of precipitation.

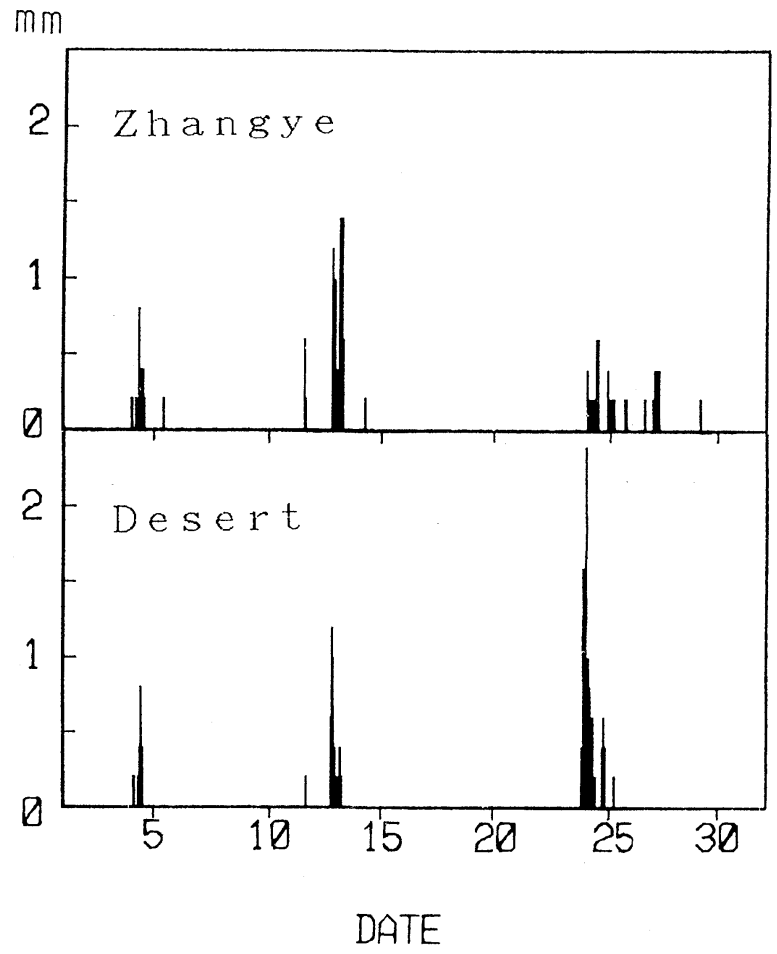

Fig. 6. Variation of precipitation at DBS and ZBS in August, 1991 plotted every $30 \mathrm{~min}$.

Nearly the same situation existed between the wind direction and precipitation in the other wet periods, except the second one. In the case of the second wet period, precipitation was not observed but the wind direction turned to southeasterly. So the second wet period seems to be also affected by the monsoon.

Concerning wind speed, there is no clear relation to the wet period; if anything, wind speed is rather weak during the wet period.

At the end of the preceding section, the author mentioned a relation between the period of precipitation and a peak of atmospheric pressure. Tan and Zheng (1993) suggested that there is an anticyclone at the foot of the Tibetan Plateau produced by orographic effects in the summer season. They revealed this anticyclone to be one of the mean climatic characteristics of the HEIFE area. We will examine whether the peak of the atmospheric pressure shown in Fig. 7 is caused by the reason suggested by Tan and Zheng (1993) or by a traveling anticyclone.

The path of the anticyclones around the HEIFE area at the third wet period is shown in Fig. 9, referring to the weather map issued by the Japan Meteorological Agency. We can see that one of the anticyclones is traveling along the edge of the Tibetan Plateau from the west to the east. Higher atmospheric pressure which appears at the same time as the precipitation as shown in Figs. 6 and 7 seems not 


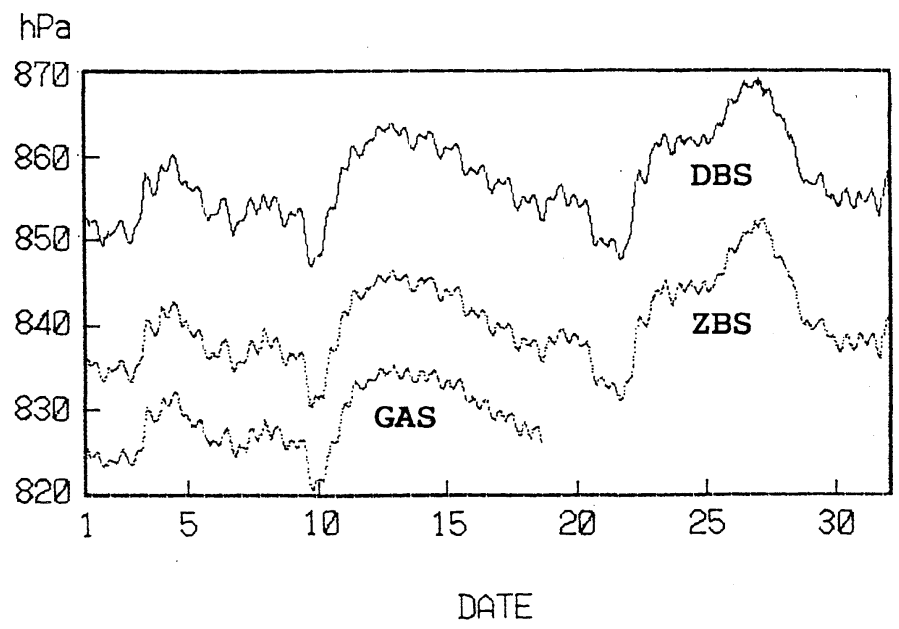

\section{- DESERT … ZHANGYE $\cdots$ GOBI SOUTH}

Fig. 7. Same as Fig. 6, but for atmospheric pressure.

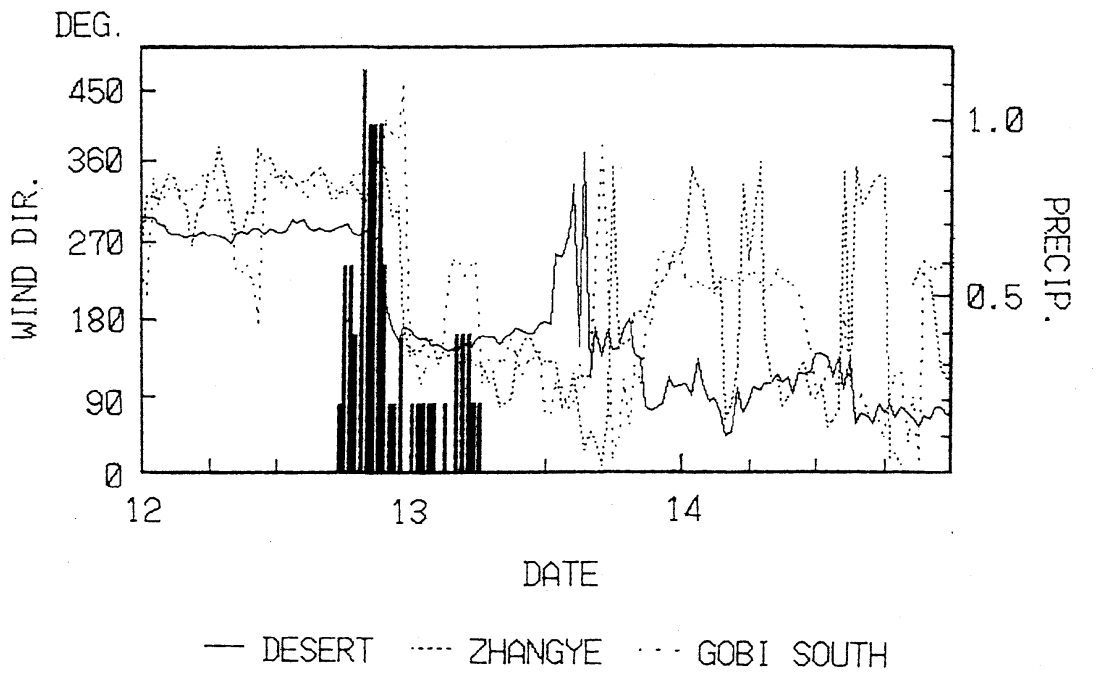

Fig. 8. Time change of wind direction at DBS, ZBS, GAS and precipitation at DBS during the third wet period, plotted every $30 \mathrm{~min}$.

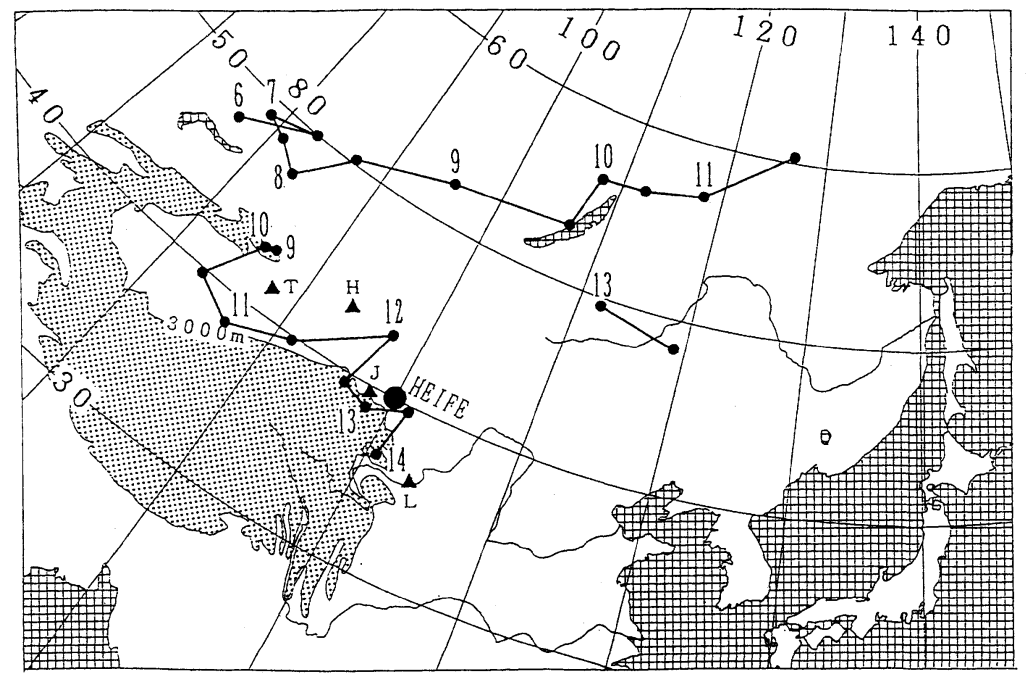

Fig. 9. Path of anticyclones near the HEIFE area around the third wet period. Small black circles show the location of the anticyclone at the specified date written beside the circle. A triangle shows the observation site referred to in Fig. 10. Abbreviations of the site are; T: Tikanrik, H: Hami, J: Jiuquang, L: Lanzhou. 


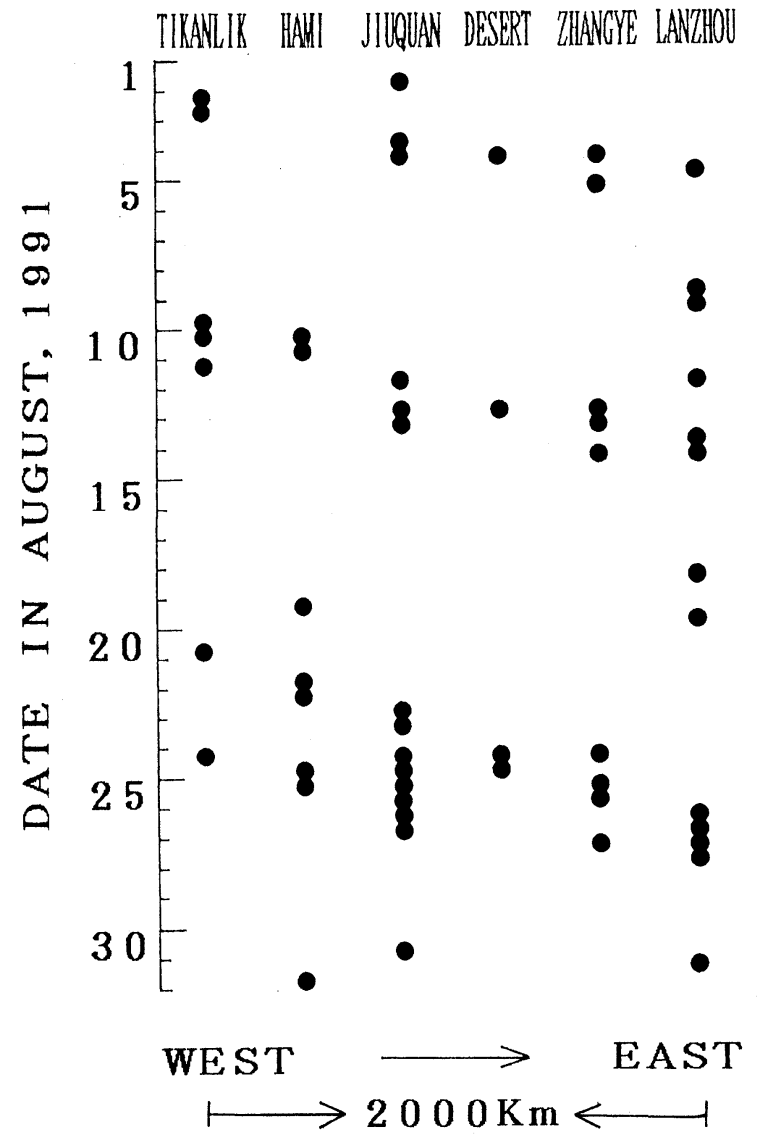

Fig. 10. Space-time distribution of precipitation. Each black circle shows the date of the rainfall. The location of the observation sites is shown in Fig. 9.

to be caused by a stationary anticyclone produced by an orographic effect as was suggested by Tang and Zheng (1993). Figure 10 shows the space-time distribution of precipitation at several sites near the HEIFE area. Comparing with Fig. 9 and Fig. 10, it can be seen that precipitation area moves accompa- nied by the anticyclone.

With Fig. 10, we can see that precipitation area during the first and the fourth wet periods was also traveling from the west to the east.

\section{Concluding remarks}

In summer season, a wet period which seems to be accompanied by a monsoon from the Indian Ocean is found in the HEIFE area including the Desert Basic Station. The size of the phenomenon is at least as large as the HEIFE area. During the wet period, the air temperature is lower and the solar radiation is less.

In some cases, the precipitation in the summer season in this area occurs under the interaction of the monsoon from the Indian Ocean and the traveling anticyclone. The detailed mechanism of this is not yet clear; it requires more consideration in connection with the upper air data.

\section{Acknowledgement}

The author would like to express his hearty thanks to Prof. Y. Mitsuta, Disaster Prevention research Institute, Kyoto University for his encouragement throughout this study.

\section{References}

Tan, M.C. and G. Zheng, 1993: History and climatology of HEIFE area, Hexi Corridor. Proc. Int. Symp. HEIFE, 6-15.

Yatagai, A. and T. Yasunari, 1933: The precipitation and water vapor transport over and around the arid and semi-arid regions of China. Proc. Int. Symp. HEIFE, 51-61.

Yoshino, M., 1993: Atmospheric circulation in the arid and semi-arid region in China. Proc. Int. Symp. HEIFE, 39-50.

Wang, J., Y. Hu, K. Sahashi and Y. Mitsuta, 1993: Outline of HEIFE field observation. Proc. Int. Symp. HEIFE, 22-29.

\title{
HEIFEの砂漠基本観測点での湿潤期
}

\author{
佐橋 謙 \\ (岡山大学教育学部)
}

HEIFEの砂漠基本観測点で、夏季に比較的大きな比湿の变動が見られた。8月一カ月間の最大值は最小 值の 3 倍もの大きさであった。この現象の範囲は HEIFE 領域を覆うくらいの大きさであり、その時気温、 日射量は低下し、風向がインド洋からのモンスーンと思われる南東から東の風に変わる。また、降水を伴 うことが多い。さらに、この現象は移動性高気圧に伴うようであるが、その機構は不明である。 